\title{
The Research of Low- Molecular Protectors in Taraxacum Officinale Wigg. in Connection with Mining Waste Utilization
}

\author{
Irina Egorova ${ }^{1,{ }^{*}}$, Olga Neverova $^{2}$, and Tatyana Grigorieva ${ }^{3}$ \\ ${ }^{1}$ The Federal Research Center of Coal and Coal Chemistry of SB RAS (Institute of Human Ecology \\ of the SB RAS), Leningradskiy avenue, 10, Kemerovo, 650065, Russia \\ ${ }^{2}$ Kemerovo State University, 73, Sovietskiy pr., Kemerovo, 650000, Russia \\ ${ }^{3}$ T.F. Gorbachev Kuzbass State Technical University, 650000, 28 Vesennyaya St., Kemerovo, Russia
}

\begin{abstract}
This paper presents a research on the content of low-molecular metabolites possessing protecting properties (free proline, reducing sugars, succinic acid) in Taraxacum officinale Wigg. which grows on the mining wastes of Kedrovsky open pit in Kemerovo region. The paper also researches the topic of relation between the content of the above substances and morphometric characteristics of the plant such as weight of leaves and roots, length of roots and surface area of leaves. In the course of the research in was established that adverse edaphic effects of mining waste cause adaptive changes of Taraxacum, which affect the plant on biochemical and organ level. As for biochemical level the increase in content of low-molecular protectors in leaves and roots was revealed. As for organ level the evident reduction of morphometric characteristics (weight of leaves and roots, length of root, surface area of leaf) was revealed which can be interpreted as an evidence of xerophytesation increasing the plant's survivability in hostile environment. The revealed adaptive changes described above form the plant's resistance to the extreme environmental factors and present an evidence of plant's ability to fully conduct its vital functions in the conditions of the mining waste.
\end{abstract}

\section{Introduction}

Due to coal mining more than 100000 hectares of land in Kemerovo region are damaged. Approximately 20000 hectares were recultivated during the recent years. The process of biological recultivation goes simultaneously with natural overgrowing of mining wastes. Lack of moisture, failed water permeability, contrasting air temperatures on different heights, low potential fertility of soil negatively affect recultivation process [1]. Due to these negative factors, at the earlier stages of phytocenosis development, only a limited number of plant species can grow.

Taraxacum officinale Wigg. is One of the first plant which settle on the coal mines and occupies large territory. This is a perennial herb of the Aster family (Asteraceae), with a tapeworm, fleshy root. The stem of the plant is absent. Leaves are oblong-lanceolate,

\footnotetext{
* Corresponding author: nir kem@mail.ru
} 
sinuate-peritonektomie collected in the root socket. Floral hand long is cylindrical, hollow, carries a big basket with flat receptacle and Golden-yellow ray flowers with crest upstairs. All parts of the plant contain a milky juice. Blooms from spring to autumn.

It found in all areas everywhere in the fields, near houses, along roads, on fallow lands, pastures and birch forests, meadows forming quite large thickets in Kemerovo region. The thickets of dandelion medicinal has been increase in recent years (territory of abandoned villages, unprocessed fields, etc.). Taraxacum officinale Wigg.grows on different types of dumps, as a part of various communities [2].

The level of resistance is defined by adaptive capabilities of the plant. In various literature sources there is a large proof base sustaining the fact of normal functioning of general resistance mechanisms in plants exposed to various stressors [3-5].

A significant role in increasing the resistance level of plants on cellular and tissue level is played by low-molecular protectors (sugar, proline, several organic acids, etc.) $[6,7]$.

Due to the above, the goal of this paper is to research the morphometric features and concentration of low-molecular metabolites - free proline, reducing sugars, succinic acid which have protective capabilities in Taraxacum officinale Wigg., growing at the mining waste areas of Kemerovo region.

\section{Materials and Methods}

The research has been conducted at the territory of mining waste area of Kedrovsky open pit. The earth relief of mining waste shares plain and inclined features with height of $58 \mathrm{~m}$. and square area of 599 hectares. The mining waste is constituted from sand rock $(60 \%)$, siltstone $(20 \%)$, mudstone (15\%), loamy soil and clay (5\%).

The experimental area is situated at the top of the mining waste area (geographic coordinates N 55 $30^{\prime} 39^{\prime \prime}$ E $\left.86^{\circ} 04^{\prime} 00^{\prime \prime}\right)$. The biocenose has been existing for $7-10$ years. Both technical and biological (planting of Pinus sylvestris L. и Onobrychis arenaria (Kit.) DC.) recultivation stages have been finished. The signs of early stage formation of poium are visible. Some parts of rocky soil with square area $3 \mathrm{~m} 2$ formed from different kinds of waste soil are completely lacking any form of vegetation. Projective cover is up to $50 \%$, while on rocky soil it is less than $10 \%$. The soil is not matted. The following herbs are prevail in the area Onobrychis arenaria (Kit.) DC., Taraxacum officinale Wigg., Melilotus officinalis (L.) Pall., Artemisia sericea Web. ex Stechm., Picris hieracioides L.

Embriozems which are characterized by alkaline reaction ( $\mathrm{PH}$ aqueous extract 7.1-7.7), average humus concentration ( $3.5 \%$ ), low concentration of movable forms of phosphorus $(10 \ldots 50 \mathrm{mg} / \mathrm{kg})$, nitrogen $(3.6 \ldots 6.0 \mathrm{mg} / \mathrm{kg})$, rich concentration of potassium $(100 \ldots 140$ $\mathrm{mg} / \mathrm{kg}$ ), lack of productive moist (19-22 $\mathrm{mm}$ in $0 \ldots 20 \mathrm{sm}$. layer of soil).

Experimental area is situated $15 \mathrm{~km}$. north-west from mining waste bordering birch forest. The major area (approx. 80\%) is occupied by grain-herb meadow. Projective cover ranges from $95-100 \%$, the soil is not matted.

Among the herbs growing on the meadow the following herbs prevail Centaurea scabiosa L., Hieracium umbellatum L., Lathyrus pratensis L., Achillea Asiatica Serg., Taraxacum officinale Wigg. The soil of the area can be characterized as black earthmeadow heavy loam soil rich with humus (9.65\%), relatively high concentration of phosphorus $(83 \mathrm{mg} / \mathrm{kg}$ ) and potassium $(171 \mathrm{mg} / \mathrm{kg})$ [8], subacid reaction of soil solution (pH 6.1..6.3) and sufficient supply of productive moisture $(50-60 \mathrm{~mm}$ in $0 \ldots 20 \mathrm{sm}$. layer).

The objective of this research is Taraxacum officinale Wigg. since it's the most widespread perennial herb growing at mining waste. The samples were gathered during dry sunny weather, according to the general rules and during the period of maximal development of vegetative mass $(05.06 .2016)$. The samples gathered were without visual signs of damage. Samples were taken from 15 experimental sites of $1 \mathrm{~m} 2 \mathrm{each}$. The average 
sample was then prepared via quartering according to the governmental standard GOST 24.027.0-80. The average mass deviation of samples was within $\pm 10 \%$ mark.

The quantity of free proline was measured by spectrophotometric method with ninhydrin reagent [9], concentration of reducing sugars was measured by spectrophotometric method with copper glycerates reagent [10]. The measurements were taken 3 times.

The concentration of succinic acid in herbal extracts was measured via tandemic massspectrometric method on liquid chromatograph UltiMate 3000 (produced by Dionex) equipped with mass-spectrometric detector QTrap3200 (produced by ABSciex). Measurement conditions: column: PhenomenexHydro-RP C18, 250×4.6 mm, particle size 4 micrometers. Column temperature: 35 degrees. Eluent: acetonitrile: acetate buffer $20 \mathrm{mM}$, gradient 2-95\% of acetonitrile. Flow speed: $0.5 \mathrm{mil} . / \mathrm{min}$. Sample volume $20 \mathrm{mcl}$. Detecting: mass-spectomatic, source of ionization - electric sprey. Potential on minute vessel $-4.5 \mathrm{kw}$, source temperature $500^{\circ} \mathrm{C}$, declusterization potencial $-15 \mathrm{~V}$.

Quntitive measurement of succinic acid in extracts was done in optimized conidtions based on MRM-transitions by automatic measurement of area of signals and its comparison with calibrating graphs of internal standards.

The following morpho-biometric characteristics were used as integral index of successful growing of Taraxacum officinale Wigg. : mass of underground and overground part of the plant, square area of leaves and length of root.

For morpholofical measurement 10 samples were taken from each experimental site, 150 samples in total were measured.

Square area of leaves was measured by scaning and further image processing with Image Tools software.

Mathematical processing and interpretation of measurement results was done via software Statistika 8.0 and descriptive statistics.

\section{Results and Discussion}

The results of the experiments are gathered in the table 1 . The analysis of allocation of lowmolecular metabolits concetration in Taraxacum officinale Wigg. showcases larger concentration of succinic acid and free proline in roots, reducing sugars are mostly concentrated in leaves. Probably the larger concentration of succinic acid and proline in roots is physiolofically caused and related to osmotec pressure which is maintained to supply water from soil to the root hair.

The comparitive analysis of concentration of low-molecular metabolites in plant samples (experimental and standard Taraxacum officinale Wigg.) showed differences.

The plants growing in conditions of mining waste area have a larger concentration of the metabolites in questions, this includes leaves and roots, however the degree of concentration increase is different.

The table indicates that concentration of free proline in leaves and roots of Taraxacum officinale Wigg. bis up to $17-18 \%$, the most signifant increase $(33 \%$ in leaves and $55 \%$ in roots) is visible in succinic acid concentration.

Apparently the lack of producvtive moisutre, contrastive air temperatures at mining waste area, low potential fertility of embriozems cause dissociation of physiological processes in the plant, which leads to reallocation of plastic substances and energy resourses, adaptive mechanisms kick in to preserve the survival of plants. 
Table 1. Concentration of several biochemical and morphometrical indicators.

\begin{tabular}{|c|c|c|c|c|c|c|}
\hline \multirow[t]{2}{*}{ Variants } & \multicolumn{3}{|c|}{ Low molecular metabolites } & \multicolumn{3}{|c|}{ Morphometric indicators } \\
\hline & $\begin{array}{c}\text { Proline, } \\
\text { mg \% }\end{array}$ & $\begin{array}{c}\text { Sugar, \% } \\
\text { of dried } \\
\text { mass }\end{array}$ & $\begin{array}{c}\text { Succinic } \\
\text { acid, } \\
\text { mcg/mg } \\
\text { samples }\end{array}$ & $\begin{array}{c}\text { Dried mass } \\
\text { from } 1 \mathrm{~g} \text {. of } \\
\text { plant }\end{array}$ & $\begin{array}{c}\text { Root } \\
\text { length, } \\
\text { sm }\end{array}$ & $\begin{array}{c}\text { Average } \\
\text { leaf S, } \\
\text { sm }^{2}\end{array}$ \\
\hline $\begin{array}{l}\text { Standard } \\
\text { plant: } \\
\text { Leaves - } \\
\text { Roots - }\end{array}$ & $\begin{array}{c}7.48 \pm 0.13 \\
58.75 \pm 1.2\end{array}$ & $\begin{array}{l}7.20 \pm 0.02 \\
5.97 \pm 0.03\end{array}$ & $\begin{array}{l}0.15 \\
0.22\end{array}$ & $\begin{array}{c}20.52 \pm 1.97 \\
5.58 \pm 0.54\end{array}$ & $12.87 \pm 1.12$ & $40.62 \pm 3.83$ \\
\hline $\begin{array}{l}\text { Experiment } \\
\text { al plant: } \\
\text { Leaves - } \\
\text { Roots - }\end{array}$ & $\begin{array}{l}8.31 \pm 0.09^{*} \\
55.66 \pm 0.16^{*}\end{array}$ & $\begin{array}{l}8.46 \pm 0.04^{*} \\
7.01 \pm 0.06^{*}\end{array}$ & $\begin{array}{l}0.20^{*} \\
0.34^{*}\end{array}$ & $\begin{array}{r}16.40 \pm 1.32 * \\
3.01 \pm 0.25^{*}\end{array}$ & $8.38 \pm 0.63 *$ & $\begin{array}{r}24.74 \pm 1.62 \\
*\end{array}$ \\
\hline
\end{tabular}

Scintific literature tells us that accumulation of proline is one of non-specific plant reactions on various stressors. Authors state that free proline concentration increases by $10 \mathrm{~s}$ 100 s of times during drought, salinization, exposure to high and low temperatures and other damaging factors [11]. Accumulation of carbons might preserve osmotic status of plants [12], increase the stability of biomembranes, antidenaturalize proteins and have antioxidant effect[13]. Aside from protecting functions, some carbons might have signal role [14]. One of non-specific reactions of a plant to various stressors can be accumulation of physiologically active metabolic products [3]. It's a known fact that when exposed to stress plants demonstrate stronger respiration which activates the Krebs cycle, triggering the increase in concentration of di- and tri-carbone acids, including succinic acid. Literature sources tell us that succinic acid increases frost and drought resistance, plants immunity to diseases, has an ability to disarm free radicals and has strong antioxidant effect [15]. Strong respiration during stress causes the plant growth to slow down, since growth is one of the major energy consumers.

With high probability it's possible to state that in the conditions of mining waste the weight of leaves of Taraxacum officinale Wigg.decreases by $20 \%$, average leaf square area decreases by $39 \%$ while weight and length of root decreases by $46 \%$ and $35 \%$ respectively. (Table .1, Fig 1.).

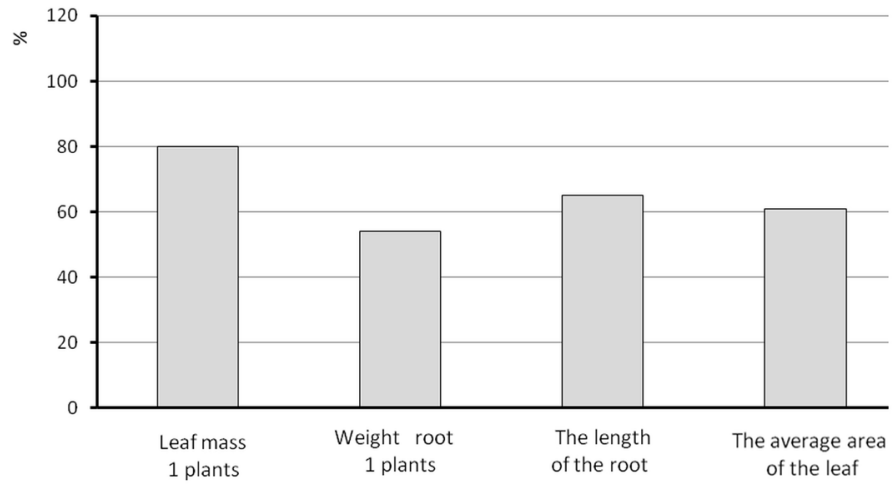

Control taken as $100 \%$.

Fig 1. Morphometric indicators of Taraxacum officinale Wigg. (\% of control). 
The revealed morphometric changes can be considered a demonstration of xerophytization - an adaptive reaction which takes place at the level of a plant as a whole, aimed at survival in unfavorable conditions of mining waste.

\section{Conclusion}

Unfavorable edaphic conditions of mining waste near Kedrovsky open pit cause adaptive reconstruction of Taraxacum officinale Wigg. which affects biochemical and organic structure of the plant. As for biochemical level Taraxacum officinale Wigg. displays increased concentration of low-molecular protectors (free proline, reducing sugars and succinic acid) in leaves and roots. On organic level, the adaptation towards unfavorable conditions of mining waste area is seen in increased level of xerophytization, which is evident by decreasaed size of hebr organs - square area of leave and lentgh of root, as well as decreased weight.

\section{Acknowledgement}

The work was carried out according to the state task - No 0352-2016-0002.

\section{References}

1. Y. Manakov, Revegetation in technogenic landscapes of Kuzbass (KemSU, Kemerovo, 2012).

2. O.A. Neverova, I.N. Egorova, Modern problems of science and education. 6, 502 (2016)

3. I.Yu. Usmanov, Z.F. Rahmankulova, A.Yu. Kulagin, Ecological plant physiology: tutorial (Logos, Moscow, 2001)

4. O. A. Neverova, Environmental assessment of the state of woody plants and pollution of the industrial city (on the example of Kemerovo) (KemSU, Kemerovo, 2004)

5. V.K. Girov, E.I. Golubev, A.F. Govorova, A. H. Haitbaev, Structural and functional changes of vegetation in conditions of technogenic pollution in the far North (Nauka, Moscow, 2007)

6. A. R Garifzyanov, S. V. Gorelova, V. V. Ivanishchev, Izvestiya of the Tula state University. Series: Natural Sciences.1, 166-178 (2009)

7. Yu.E. Kolupaev, Yu.V. Karpec, Formation of Adaptive responses of plants to the action of abiotic stressors (Aqua, Kiev, 2010)

8. O. I. Prosyannikova, Anthropogenic transformation of soils in the Kemerovo region (KemSU, Kemerovo, 2005)

9. O. L. Voskresenskaya, E. A. Alyabysheva, M. G. Polovnikova, Large workshop on Bioecology: the textbook (Imago, Yoshkar-Ola, 2006)

10. G. G. Filipova, I. I. Smolich, Biochemistry of plants: methodical recommendations to laboratory occupations, tasks for independent work of students (BGU, Minsk, 2004)

11. P.D. Hare, W.A. Cress, J.V. Staden, J. Exp. Bot., 5, .413-434 (1999)

12. M. Kofi, V. S. Stewart, A. M. Borland, Russ. J. of Plant Physiology. 50:2, 174-182 (2003)

13. Yu.V. Karpets, Yu.E. Kolupaev, Bulleting of Kharkiv National Agrarian University. 1: 16, 19-38 (2009) 
14. F. Rolland, J. Sheen, Biochem. Soc. Trans. 33, 269-271 (2005)

15. V.V. Kropotkina, Bulleting of ASAU, 8:58, 30-34 (2009) 